\title{
개발원조위원회(DAC) 회의 결과
}

11.14 15간 개발원조위원회(DAC) 회의가 개최되 어, 금년 SLM 의제 및 일정(안), 취약국가에 대한 자 금흐름 모니터방안, 원조의 untying 확대방안, DAC 수원국 리스트 개정, 커뮤니케이션 전략 등에 대하여 논의한 바, 주요 내용은 아래와 같음.

\section{I . 핵심요지}

ㅁ DAC는 원조효과 증진 차원에서 2001년에 채택된 '최빈국 $\mathrm{ODA}$ 의 Untying에 관한 권고문' 의 적용 범위 확대(중저소득국으로 확대 등)를 검토 중인 바, 우리의 $\mathrm{ODA}$ 사업에 미치는 영향에 대하여 검 토할 필요가 있음.

\section{II. 세부논의내용}

\section{1. 금년 SLM 일정 및 의제}

가. 12.6 (화)

ㅁ 11:00 12:30 - Non-DAC 공여국과의 대화

14:00 18:00 - WB와의 공동회의

- 의제 : ODA 규모 확대 후속조치 논의

ㅁ 19:30 - 수석대표 만찬

- 의제 : 원조효과 모니터링, 쓰나미 원조공약 이

행 점검, 아프리카 개발문제

나. 12.7(수)

ㅁ 09:30 - (1) 의제 채택, (2) 취약국가

ㅁ 12:00 - (3) Untying에 대한 향후 추진계획

(4) $\mathrm{DAC}$ 수원국 리스트 개정문제

ㅁ 13:00 - 수석대표 오찬

- 의제 : 능력개발의 도전

ㅁ 15:00 - (5) 2008년까지 작업 우선순위 및 자발적 기여금, (6) 2006년도 HLM 의제 
※SLM 의제 및 일정 상세는 DCD/DAC/A(2005)17/REV1 참조

\section{2. 취약국가에 대한 자금흐름 모니터방안}

ㅁ취약국가를 방치할 경우, 국제안보 및 $\mathrm{MDG}$ 달성 을 위한 개발노력에 중대한 타격을 초래할 우려가 있기 때문에, 2005년 1월 런던에서 개최된 '취약 국가의 개발효과에 관한 고위급포럼' 은 DAC 사 무국이 취약국가에 대한 자금흐름을 모니터하고 동 결과를 금년 12 월 SLM에 보고하도록 결정한 바 있음. 이에 따라 DAC는 취약국가에 관한 그룹 (FSG)을 구성하여 취약국가에 대한 자금흐름 현 황을 조사 연구하여 왔는 바, 1 차 보고서를 금년 $\mathrm{SLM}$ 에 상정할 예정임.

ㅁ일부 취약국가들은 특별한 이유 없이 국제사회의 원조실적이 저조하거나, 원조규모가 갑자기 축소 또는 급변하여 많은 어려움을 겪고 있는 바, 이러 한 취약국가에 대한 자금흐름을 파악하여 공여국 의 자원배분에 관한 결정시 참고할 수 있도록 하 자는 것이 기본 취지임.

동 보고서는 $\mathrm{WB}$ 의 자료를 기초로 하여 35 개 원조 대상국에 대하여 원조필요성 및 원조규모, 거버넌 스, 원조흐름의 가변성, 향후 원조흐름 전망 등 8 개 분야로 나누어 검토한 결과, 부룬디, 중앙아, 차드, 기네비사우, 니제, 시에라레온, 타지키스탄, 토고 등 8개국이 가장 소외된 취약국으로 분류된 다고 하며, 이들 국가에 대한 원조흐름을 계속 모 니터할 필요가 있다고 함.

ㅁ 보고서는 상기 방법론에 대한 DAC 회원국의 동의 여부 및 조사결과의 활용방안에 대한 회원국의 의
견을 문의하고 있는 바, 금년 SLM에서 논의하여 향후 방향을 제시하기로 하였음(상세는 $\mathrm{DCD} / \mathrm{DAC}(2005) 48$ 참조).

\section{3. 원조의 untying 확대방안}

ㅁ DAC는 2001년도 원조의 untying에 관한 권고문 의 효과를 확대하고 개도국의 요청에 대응하기 위 하여 untied aid의 혜택을 확대하는 방안에 대하 여 논의해왔는 바, 사무국은 4 개 방안을 제시함.

믁ㄱㅎㅣ 2001년도 untying에 관한 권고문이 70만 $\mathrm{SDR}$ 이하 규모의 활동(기술협력의 경우 13 만SDR 이하 규모)에 대해서는 권고문 적용을 배제시킨 바, 금년 SLM에서 이러한 coverage threshold를 폐지하여 규모에 상관없이 권고문을 적용하는 방 안에 대하여 합의에 도달할 것을 제안함.

아울러, 2001년도 권고문이 최빈국에 대해서만 적 용하게 되어 있으나, $\triangle$ 대상 국가의 범위를 최빈 국뿐만 아니라 중저소득국으로 확대하는 방안, $\triangle$ 현지구매를 확대하는 방안, $\triangle$ 기술협력사업도 일 부 분야에 대해서는 untying을 적용하는 방안에 대해서는 계속적 논의를 통해 합의를 모색할 것을 제안한 바, 금년 SLM에서 중점 논의하기로 하였 음(상세는 $\mathrm{DCD} / \mathrm{DAC} /(2005) 49$ 참조).

\section{2001년도 untying 권고문의 이행현황}

ㅁ 오지리, 그리스, 아일랜드 및 룩셈부르크가 자국 의 ODA는 2001 년도 권고문의 적용대상에 해당되 지 않는다고 사무국에 공식 통보하였으며, 이에 따라 사전통보 또는 사후계약 보고 등 관련정보를 
제공하지 않고 있음.

ㅁ 회원국의 보고사항중 $95 \%$ 는 권고문에서 규정한 바와 같이 상세한 정보를 제공하고 있으며, 다만 입찰기한을 명확하게 제시하지 못하고 있는 문제 점이 있으나, 이는 수원국 조달기관을 활용하거 나, 또는 특별한 프로젝트가 아니라 범위가 넓은 활동을 통보하기 때문임.

ㅁ 결론적으로 권고문의 투명성 규정 준수 수준이 만 족스럽고 올바른 방향으로 나가고 있으나 사후에 계약현황에 대한 보고를 강화하여 투명성을 개선 할 여지는 있다고 함. 아울러 권고문의 이행현황 을 앞으로도 매년 검토할 필요가 있다는데 합의함 (상세 $\mathrm{DCD} / \mathrm{DAC}(2005) 44$ 참조).

\section{5. 빈곤 친화적 성장(Pro-poor growth)}

ㅁ DAC는 2001년에 빈곤감축가이드라인을 채택하 였고, 빈곤감축작업반(POVNET)은 경제성장이 빈곤감축에 기여하는 방안을 중점 연구해왔는 바, 아래와 같은 주요결론을 도출함.

- 경제성장율 뿐만 아니라 경제성장의 패턴, 경제 성장의 지속가능성, 격차 완화에 대해서도 효과 가 있는 다양한 정책을 동시에 추진할 경우 빈 곤감축에 효과적임.

- 빈곤 친화적 성장을 위한 특별한 청사진은 없으 며, 개도국이 주도하는 빈곤완화전략에 경제성 장 정책 및 비경제 부문의 발전정책, 정책 및 제 도개선을 병행하여 추진되어야 함.

- 민간부문 개발, 농업 및 인프라 부문 개발은 빈 곤친화적 시각에서 볼 때, 과거에 추진하던 전
략을 다수 수정할 필요가 있음.

- 공여국은 파리선언에 규정된 원칙에 따라 원조 효과를 증진하는 방식으로 빈곤친화적 성장에

대한 원조규모를 확대할 필요가 있음.

ㅁ금년도 SLM에서 상기 빈곤친화적 성장에 대한 POVNET의 연구결과에 대하여 논의하고 이를 2006년도 HLM에 상정하는 방안에 대해서도 의 견을 나누기로 함(상세 $\mathrm{DCD} / \mathrm{DAC}(2005) 50$ 참조).

\section{DAC 수원국 리스트 개정}

미난 9 월 회의시 기존의 $\mathrm{DAC}$ 수원국 리스트는 Part I 및 Part II 국가로 구분하였으나, 이를 구분 하지 않고 단일 수원국 리스트로 개정한다는 원칙 에 합의한 바 있음.

ㅁ 그러나, 지난 9월회의시 기존의 리스트에서 Part II 국가인 벨라루스, 리비아, 우크라이나를 개정된 수원국 리스트에 포함시키는 문제, 사우디아라비 아 (1인당 소득 10,430 불)를 고소득국으로 분류하 여 졸업시키는 문제에 대한 이견으로 인해 추후 재검토키로 한 바 있음.

이번 회의에서도 덴마크, 노르웨이 등은 사우디아라 비아와 같은 고소득국, 벨라루스, 리비아, 우크라이 나 등의 중소득국이 수원국 리스트에 추가로 포함되 는 것에 대하여 계속 유보적이라는 입장을 표명함에 따라 2006년 발효(2005년도 ODA 통계부터 적용) 를 위해 금년 12 월 SLM 회의시 다시 논의하여 채택 하기로 함(상세 $\mathrm{DCD} / \mathrm{DAC}(2005) 51$ 참조).

[자료:주오이시디 대표부] 